\title{
Factors Affecting Adoption of Good Agricultural Practice of Rubber (Hevea brasiliensis) Orchard in Jhapa, Nepal
}

\author{
Basanta Khanal ${ }^{1 *}$, Jaya Prakash Dutta ${ }^{2}$ and Purnima Puri ${ }^{3}$ \\ ${ }^{1}$ Department of Agriculture, Agriculture and Forestry University, Rampur, Chitwan, \\ Nepal \\ ${ }^{2}$ Department of Economics and Agribusiness Management, Dean at Agriculture \\ and Forestry University, Nepal \\ ${ }^{3}$ Agriculture and Forestry University, Rampur, Chitwan, Nepal \\ *Corresponding Author: Basanta Khanal, Department of Agriculture, Agriculture \\ and Forestry University, Rampur, Chitwan, Nepal.
}

Received: March 16, 2021

Published: April 26, 2021

(C) All rights are reserved by Basanta Khanal., et al.

\section{Abstract}

The study was conducted to determine adoption of good agricultural practices of rubber (Hevea brasiliensis) orchard and factors affecting its adoption. Seventy rubber growing farmers were selected by using simple random sampling technique. Data were collected with pre tested semi structured interview schedule during month of April, 2020. Chi-square test, Pearson coefficient of correlation and Independent t-test were used to analyze the data. Findings of the study revealed that out of eight management practice; Basin size (87.1\%) was highly adopted while Chemical fertilizer application (22.9\%) was least adopted. About $60 \%$ of rubber farmers had high adoption level and remaining $40 \%$ had low adoption level for good agricultural practice. Among selected factors; farm size (at 1\% level), training (at 1\% level) and frequency of contact with extension worker (at 5\% level) had significant association with adoption level of good agricultural practices of rubber. Similarly adoption level of good agricultural practices was found to be significant with income (at 1\% level) and productivity (at 1\% level). Farmers with high adoption level had yearly income of 5.59 lakhs/ha and latex productivity of 3.04 Mt/ha while farmers with lower adoption level had yearly income of 2.13 lakh/ ha and latex productivity of $1.23 \mathrm{Mt} / \mathrm{ha}$. Poor technical knowledge, price fluctuation in combination with high cost of input is limiting adoption of good agricultural practices.

Keywords: Adoption Level; Significant Association; Rubber; Good Agricultural Practice

\section{Introduction}

Natural rubber is known as White Gold [1] which can be obtained from more than 2000 species of 300 genera [2]. Para rubber or Hevea brasiliensis is the most commercially developed species of natural rubber in the world, which accounts $99 \%$ of global natural rubber production. Natural rubber is raw material with greater industrial strategy value and among the most diverse agricultural products, which is found to be used in about 50000 products [3] like tyre, tubes, automobile parts, battery boxes, footwear, wires, belts, cables etc.
Rubber was introduced in Nepal during 2046 B.S in collaboration of government of Nepal gorakhhali rubberudhyog, sudhafalrus Pvt. Ltd and some Indian experts on 5 ha land with the vision to perform plantation test, geographical, climatic and edaphic suitability [4]. According to report of PMAMAP, (2019) 15,000 to 20,000 ha land of eastern terai namely Jhapa, Morang, Sunsari and lower part of Illam were considered potential for rubber production. Despite of such climatic suitability only 555 ha of land is under rubber cultivation with production of $269 \mathrm{Mt}$ and productivity of $1.1 \mathrm{Mt} /$ ha. In Nepal there is a huge gap between rubber production and 
consumption. Import of rubber and rubber related good in 2018 is of worth $8,307,815,000 \mathrm{Nrs}$ while export of worth $18,207,000 \mathrm{Nrs}$ with a trade deficit of $-8,289,608,000 \mathrm{Nrs}$ [5]. Demand of rubber and rubber related goods are more than its supply which shows the scope of rubber cultivation in Nepalese context.

According to FAO, Good agriculture practices are set of principles that are applied during pre-production and post-production processes for safe and healthy agricultural products considering economic, environmental and social sustainability. Adoption of GAP will help to promote sustainable agriculture and to achieve national and international goals for environmental and social development [6].

Adoption of recommended package of practice plays vital role in production and productivity but various factor influences this aspects. Adoption is a dynamic decision process involving information acquisition and learning-by-doing by growers who vary in their managerial abilities, risk preferences, and their perceptions of the profitability and riskiness of the innovation [7]. Perception of farmers towards a new technology is a key precondition for adoption [8]. According to Roger [9] adoption of technologies depends on their characteristics: compatibility with the existing values and norms and relative advantage.

\section{Materials and Methods}

Study area

Study was conducted in Jhapa district of province no. 1. Jhapa district lies at $26.6398^{\circ} \mathrm{N}$ latitude and $87.8942^{\circ} \mathrm{E}$ longitude and around 500 meter above sea level. It is bordered by Ilam at North, Morang at West and by India on East and South.

\section{Sample and sampling technique}

Five municipalities (Kankai, Arjundhara, Mechi, Bhadrapur, Damak) and 3 rural municipalities (Buddhashanti, Barhadarshi, and Kachanakawal) of Jhapa district are used for the study. According to information provided by PMAMP office a total of 147 farmers were involved in rubber cultivation among which 70 farmers were selected by using simple random sampling technique.

\section{Data source and data types}

Primary data were collected from rubber growing farmer within study area by using research instruments like household survey, field visit, key informant interview and focus group discussion. Secondary data were collected from websites of various reputed na- tional and international agencies, different rubber related books, reports and publication of various NGO and INGO, publications of MOAD, NARC, PMAMP, DADO and other government agencies.

\section{Data analysis}

Qualitative and quantitative analysis was done by using SPSS version 16, Ms-excel 2010.

\section{Chi-square test}

Chi-square test $\left(\chi^{2}\right)$ was used to study the association between two variables (dependent and independent). It is widely used method to judge the significance of association between attributes.

Chi-square is symbolically written as $\chi^{2}$

Formula,

$\chi^{2}=\sum \frac{\left(\mathrm{O}_{\mathrm{ij}}-\mathrm{E}_{\mathrm{ij}}\right)^{2}}{\mathrm{E}_{\mathrm{ij}}}$

Where, $\chi^{2}=$ Chi-square

$\mathrm{O}_{\mathrm{ij}}=$ observed frequency of each $\mathrm{ij}^{\text {th }}$ term

$E_{i j}=$ indicates expected frequency of $\mathrm{ij}^{\text {th }}$ term

$\mathrm{i}=1,2,3 \ldots \ldots \ldots . \mathrm{r}$

$\mathrm{j}=1,2,3 \ldots \ldots \ldots . \mathrm{k}$

$\mathrm{df}=(\mathrm{c}-1)(\mathrm{r}-1)$

Where, $\mathrm{c}=$ means the number of columns and $\mathrm{r}$ means the number of rows

This was tested at $0.01,0.05$ and 0.10 level of probability for different degree of freedom.

Pearson correlation of coefficient

$$
r=\frac{n \sum x y-\left(\sum x\right)\left(\sum y\right)}{\left.\sqrt{\left(n \sum x^{2}-\left(\sum x\right)^{2}\right.}\right)\left(n \sum y^{2}-\left(\sum y\right)^{2}\right.}
$$

Where

$\mathrm{r}=$ Pearson coefficient of correlation

$\mathrm{n}=$ No. of observation being correlated

$\sum \mathrm{xy}=$ Sum of product of $\mathrm{x}$ and $\mathrm{yx}$ and $\mathrm{y}=$ variable being correlated

$\sum \mathrm{x}=$ Summation over all the cell entries of the first variable

$\sum \mathrm{y}=$ Summation over all the cell entries of the second variable 
$\sum x^{2}=$ Sum of all the squared value of each cell of the first variable

$\sum y^{2}=$ Sum of all the squared value of each cell of the second variable

This was tested at $0.01,0.05$ and 0.10 level of probability.

\section{Independent t-test}

The independent $\mathrm{t}$-test was conducted to find out the association of variables singly i.e. keeping other variables constant. Here adoption level was considered as dependent variable whereas income and productivity as independent variables. The formula for independent t-test is as follow:

- Let us consider that A and B represent the two groups to compare.

- Similarly, let $\mathrm{m}_{\mathrm{A}}$ and $\mathrm{m}_{\mathrm{B}}$ represent the means of groups $\mathrm{A}$ and B, respectively.

- In the same way, let $\mathrm{n}_{\mathrm{A}}$ and $\mathrm{n}_{\mathrm{B}}$ represent the sizes of group $\mathrm{A}$ and $\mathrm{B}$, respectively.

The $t$ test statistic value to test whether the means are different can be calculated as follows:

$$
\mathrm{t}=\frac{\mathrm{mA}-\mathrm{mB}}{\sqrt{\frac{s^{2}}{\mathrm{n} A}-\frac{s^{2}}{n B}}}
$$

$\mathrm{S}^{2}$ is an estimator of the common variance of the two samples. It can be calculated as follows:

$$
\mathrm{S}^{2}=\frac{\sum(\mathrm{x}-\mathrm{mA})^{2}+\sum(\mathrm{x}-\mathrm{mB})^{2}}{\mathrm{nA}+\mathrm{nB}-2}
$$

Management practice to determine adoption level

Eight agricultural practices were considered for the study as presented in table 1 . These management was coded as 1 for the response "who uses recommended dose" and coded as 2 for the response "who does not use recommended dose". Some management practice like micronutrient use, irrigation, use of rubber coat and rubber processing were coded " 1 " for positive response and " 0 " for negative response.

From the response obtained from farmers, categorization of the farmers under low and high adopter categories was done. The adoption index was computed from the adoption score. The adoption score was computed by the sum of scores for adoption of eight different practices of orchard management. Adoption index developed by Karthikeyan (1994) was used.

$$
\mathrm{AI}=\frac{\text { Total adoption score obtained by an individual farmer }}{\text { Maximum score one can obtain }}
$$

\begin{tabular}{|l|c|}
\hline Management Practice & Recommended dose \\
\hline Spacing & $12^{*} 12,14^{*} 14,16^{*} 16$ feet [4] \\
\hline Basin size & $1 \mathrm{~m} 3[4]$ \\
\hline FYM application & 12 kg at the time of plantation [4] \\
\hline $\begin{array}{l}\text { Chemical Fertilizer ap- } \\
\text { plication }\end{array}$ & $\begin{array}{c}\text { For nursery } 10: 10: 4: 1.5 \text { (N:P:K:Mg) } \\
\text { For 4-7 years of age }=10: 10: 4: 2 \\
\text { (N:P:K:Mg) } \\
\text { After starting of tapping }=10: 10: 10: 4 \\
\text { (N:P:K:Mg) }\end{array}$ \\
\hline Micronutrient use & Yes $=1, \mathrm{No}=0$ \\
\hline Irrigation & Yes $=1, \mathrm{No}=0$ \\
\hline Use of rubber coat & Yes $=1$, No $=0$ \\
\hline Rubber processing & Yes $=1$, No $=0$ \\
\hline
\end{tabular}

Table 1: Agricultural practiced used in study to determine adoption level.

On the basis of value of adoption index, the respondents were grouped into two categories i.e. low adopters (less than average) and high adopters (more than average).

\section{Results and Discussion}

Socio-demographic characteristics of farmers

Socio-demographic characters like age, gender, educational level, farm size, family size and farming experience influence adoption decisions [10]. Study revealed that mean age of rubber farmers was 45.8 years, mean years of schooling was 8.13 years, mean family size was 4.41 , similarly average farm size was 1.15 ha and average farm experience was 13.9 years. Similar result was found by Poudel., et al. [11] on their study.

\begin{tabular}{|l|c|c|c|c|}
\hline Variables & Mean & SD & $\begin{array}{c}\text { Mini- } \\
\text { mum }\end{array}$ & $\begin{array}{c}\text { Maxi- } \\
\text { mum }\end{array}$ \\
\hline Age & 45.8 & 7.942 & 33 & 66 \\
\hline Year of schooling & 8.13 & 3.27 & 3 & 16 \\
\hline Farm size (ha) & 1.15 & 0.827 & 0.30 & 4.05 \\
\hline Family size & 4.51 & 1.031 & 3 & 8 \\
\hline Farming experience(years) & 13.9 & 4.721 & 25 & 8 \\
\hline
\end{tabular}

Table 2: Socio-demographic characteristics of rubber growing farmers.

\section{Extension related information}

Participation on training and contact with extension workers were considered in the study to collect information related to extension service. Extension service plays a crucial role to acquire information about modern technology which affects its adoption [12]. Study revealed that $78.6 \%$ of farmers have participated on training related to rubber cultivation. Generally PMAMP and Agri- 
culture Knowledge Center (AKC) provide training related to rubber. Adoption decisions were mainly affected by participation on training programs, farmers participated on training has higher adoption level [13]. Study found that $72.9 \%$ of respondents have seldom contact, $11.40 \%$ have frequent contact and remaining $15.70 \%$ have never contact with extension worker.

\begin{tabular}{|c|c|c|c|c|}
\hline \multicolumn{2}{|c|}{$\begin{array}{c}\text { Participation on } \\
\text { training }\end{array}$} & \multicolumn{3}{c|}{ Contact with extension workers } \\
\hline Yes & No & Never & Seldom & Frequent \\
\hline $78.60 \%$ & $21.40 \%$ & $15.70 \%$ & $72.90 \%$ & $11.40 \%$ \\
\hline
\end{tabular}

Table 3: Extension related information of rubber growing farmers.

\section{Adoption of good agricultural practices of rubber}

Correct orchard management practice is necessary condition for high production, better quality, to increase input efficiency and to lower the environmental impact [14]. Establishment of an orchard are a long term investment and require critical planning, selection of proper location and site, planting system and planting distance, varieties providing all the necessary inputs to ensure maximum production. Study revealed that basin size (87.1\%) was most adopted management practice whereas chemical fertilizer application (22.90\%) was least adopted management practice. The adoption of chemical fertilizer application, micronutrient use and irrigation is due to high cost and unavailability of inputs in time [15]. Similarly, higher adoption of spacing, basin size, and FYM application is higher due to participation on training program.

\begin{tabular}{|l|l|l|l|l|}
\hline \multirow{2}{*}{$\begin{array}{l}\text { Management } \\
\text { Practice }\end{array}$} & \multicolumn{3}{|c|}{ Adopter } & \multicolumn{2}{c|}{ Non-adopter } \\
\cline { 2 - 5 } & Number & $\begin{array}{l}\text { Percen- } \\
\text { tage }\end{array}$ & Number & $\begin{array}{l}\text { Percen- } \\
\text { tage }\end{array}$ \\
\hline Spacing & 59 & $84.3 \%$ & 11 & $15.7 \%$ \\
\hline Basin size & 61 & $87.1 \%$ & 9 & $12.9 \%$ \\
\hline FYM application & 58 & $82.9 \%$ & 12 & $17.1 \%$ \\
\hline $\begin{array}{l}\text { Chemical fertilizer } \\
\text { application }\end{array}$ & 16 & $22.90 \%$ & 54 & $77.1 \%$ \\
\hline Micronutrient use & 17 & $24.3 \%$ & 53 & $75.7 \%$ \\
\hline Irrigation & 18 & $26.0 \%$ & 52 & $74.0 \%$ \\
\hline Use of rubber coat & 55 & $78.6 \%$ & 15 & $21.4 \%$ \\
\hline Rubber processing & 39 & $55.7 \%$ & 31 & $44.3 \%$ \\
\hline
\end{tabular}

Table 4: Distribution of extent of adoption of good agricultural practice by farmers.
Level of adoption of good agricultural practices

Adoption level was computed from adoption index sore obtained by individual farmers. Study revealed that about $60 \%$ of farmers were high adopter and remaining $40 \%$ were low adopter. Prodhan and Khan [16] also found similar result i.e. most of farmers were medium and high adopter in adoption of scientific management practice of aquaculture.

\begin{tabular}{|l|c|}
\hline Adoption level & Frequency \\
\hline Low $(<0.5911)$ & $28(40)$ \\
\hline High $(>0.5911)$ & $42(60)$ \\
\hline Mean & 0.5911 \\
\hline Standard deviation & 0.175 \\
\hline
\end{tabular}

Table 5: Distribution of respondents according to level of adoption of good agricultural practice of rubber.

Figure in parenthesis indicate percent

\section{Factors affecting adoption of good agricultural practices}

Adoption of a new technology depends on a careful evaluation of many technical, economic and social factors. Adoption of the technology must be made by the individual, but it can be. Continue or stop adopting technology for a variety of personal, technical, economic, institutional and social factors focused on the availability of ideas or practices that better meet their needs [9].

\begin{tabular}{|l|c|c|c|}
\hline S.N & Factors & Chi-square value & P-value \\
\hline 1 & Age & 1.172 & $0.774 \mathrm{NS}$ \\
\hline 2 & Family size & 2.612 & $0.645 \mathrm{NS}$ \\
\hline 3 & Farm size & $12.312^{* * *}$ & 0.01 \\
\hline 4 & Education level & 7.590 & $0.22 \mathrm{NS}$ \\
\hline 5 & Farming experience & 0.078 & $0.962 \mathrm{NS}$ \\
\hline 6 & Training & $12.72^{* * *}$ & 0.01 \\
\hline 7 & $\begin{array}{c}\text { Contact with extension } \\
\text { workers }\end{array}$ & $7.718^{* *}$ & 0.021 \\
\hline
\end{tabular}

Table 6: Chi-square test for factors affecting adoption of good agricultural practices.

Note: $* *, * * *$ indicates significant at $5 \%, 1 \%$ level of significance and NS indicate non-significant. 
Farm size was found to have significant association with adoption level i.e. farmers with large farm size were higher adopter compared to small and medium farm size. Bilaliib Udimal., et al. [17] also found similar results, reported that farm size has significant association with adoption of (Nerica) rice. Participation on training also have significant association with adoption level i.e. farmers participated on training related to rubber cultivation were high adopters than non-participants. Farmers can learn different management practice by participating on training. Prodhan and Khan [16], Ntshangase et al., [18] reported similar results. Contact with extension workers have significant association with adoption level i.e. farmers with frequent contact with extension workers were high adopter compared to farmers with never and seldom contact.

Relationship of adoption of good agricultural practices with Socio-demographic and extension related information

From the study it was found that farm size and training participation had highly significant relationship, while contact with extension worker had significant relationship with adoption of Good agricultural practices of rubber.

\begin{tabular}{|c|c|c|c|}
\hline S.N & Factors & $\begin{array}{c}\text { Correlation } \\
\text { value }\end{array}$ & P-value \\
\hline 1 & Age & 0.035 & $0.774 \mathrm{NS}$ \\
\hline 2 & Family size & -0.195 & $0.106 \mathrm{NS}$ \\
\hline 3 & Farm size & $0.426^{* * *}$ & 0.01 \\
\hline 4 & Education level & 0.155 & $0.199 \mathrm{NS}$ \\
\hline 5 & Farming experience & 0.018 & $0.883 \mathrm{NS}$ \\
\hline 6 & Training & $0.413^{* * *}$ & 0.01 \\
\hline 7 & $\begin{array}{c}\text { Contact with extension } \\
\text { workers }\end{array}$ & $0.025^{*}$ & 0.062 \\
\hline
\end{tabular}

Table 7: Pearson's correlation test for factors affecting adoption of good agricultural practices.

Note: *,*** indicates significant at 10\%, 1 level of significance and NS indicate non-significant.

Independent t-test analysis of adoption level with income and productivity

Average income of farmers with high adoption level was greater i.e. 5.59 lakhs as compared to farmers with low adoption level which was 2.13 lakhs. Income was affected by adoption level of improve management practice. The difference was found to be statistically significant at $1 \%$ level of significance.
Rubber productivity was found to be higher for farmers with high adoption level of improve management practice i.e. 3.04 tons/ ha as compared to farmers with low adoption level i.e. 1.23 Mt/ ha. It was found that productivity was affected by adoption level of improve management practice. The difference was found to be statistically significant at $1 \%$ level of significance.

\begin{tabular}{|c|c|c|c|c|c|}
\hline \multirow{2}{*}{ Variable } & \multicolumn{2}{|c|}{ Adoption Level } & \multirow{2}{*}{$\begin{array}{c}\text { Mean } \\
\text { Differ- } \\
\text { ence }\end{array}$} & \multirow{2}{*}{ T-Value } & \multirow{2}{*}{$\begin{array}{c}\text { P-Val- } \\
\text { ue }\end{array}$} \\
\hline & High & Low & & & \\
\hline $\begin{array}{l}\text { Income(In } \\
\text { lakh) }\end{array}$ & $\begin{array}{c}5.59 \pm \\
0.63\end{array}$ & $\begin{array}{c}2.13 \pm \\
0.30\end{array}$ & 3.46 & $-4.926^{* * *}$ & 0.001 \\
\hline $\begin{array}{l}\text { Productivity } \\
\text { (Ton/ha) }\end{array}$ & $\begin{array}{c}3.04 \pm \\
0.16\end{array}$ & $\begin{array}{c}1.23 \pm \\
0.11\end{array}$ & 1.81 & $-9.219 * * *$ & 0.001 \\
\hline
\end{tabular}

Table 8: Independent t-test analysis of adoption level with income and productivity.

Note: ${ }^{* * *}$ Indicates significance at $1 \%$ level of significance.

Constraints encountered by rubber growing farmers in adoption of good agricultural practices

Problems listed on table 9 were identified by different formal and informal meeting with farmer, some Key Informant Interview and household interview. Poor technical knowledge rank first with 0.77 index score. Price variation rank second with 0.72 index score. Sriyalatha [19], also report fluctuating market price as a major issue among small farmers in Kalutara district of Sri Lanka lack of proper variety, high cost of input, lack of irrigation and labor unavailability rank $3^{\text {rd }} 4^{\text {th }} 5^{\text {th }}$ and $6^{\text {th }}$ with index score $0.72,0.56,0.52$, 0.45 and 0.44 respectively.

\begin{tabular}{|l|c|c|}
\hline Constraints & Index & Rank \\
\hline labor unavailability & 0.44 & VI \\
\hline Poor technical knowledge & 0.77 & I \\
\hline Lack of Irrigation & 0.45 & V \\
\hline High cost of input & 0.52 & IV \\
\hline Lack of proper variety & 0.56 & III \\
Fluctuating market price & 0.72 & II \\
\hline
\end{tabular}

Table 9: Constraints encountered by rubber growing farmers in adoption of good agricultural practices.

\section{Conclusion}

Agricultural practices like spacing, basin preparation and FYM application are highly adopted whereas chemical fertilizer ap- 
plication, use of micronutrient and irrigation were least adopted. Farmers with medium farm size, seldom contact with extension workers and participation on training were higher adopter of good agricultural practice. For selected agricultural practice, about $60 \%$ of farmers have high adoption. Poor technical knowledge, fluctuating market price in combination with high cost of input is limiting adoption of good agricultural practice.

\section{Acknowledgement}

We express our deep sense of gratitude to Agriculture and Forestry University and Prime- minister's Agriculture Modernization Project for providing opportunity and funds required to accomplish the research. We are very thankful to all those farmers who give us time despite of their busy schedule. We would like to thank PMAMP Jhapa team for their continuous support.

\section{Bibliography}

1. E Valentine Daniel. "Plantations, Proletarians and Peasants in Colonial Asia”. In Plantations, Proletarians and Peasants in Colonial Asia (2019).

2. Mooibroek H and Cornish K. "Alternative sources of natural rubber". Applied Microbiology and Biotechnology 53.4 (2000): 355-365.

3. Jergin J I and Somasundaram S. "Adoption of recommended technologies by rubber growers in Kanyakumari district of Tamil Nadu". Journal of Plantation Crops 46.2 (2018): 118-123.

4. PMAMP. Rubber Kheti Prabbidhi. Prime Minister Agriculture Modernization Project, Project Implementation Unit, Rubber Zone, Jhapa (2019).

5. MoAD. Statistical Information On Nepalese Agriculture 2017/18 (2018).

6. MUQIT A., et al. "Green Global Foundation (C. Int. J. Sustain". Crop Production 11.1 (2016): 1-3.

7. Ghadim A K A., et al. "Risk, uncertainty, and learning in adoption of a crop innovation”. Agricultural Economics 33.1 (2005): $1-9$.

8. Mwangi M and Kariuki S. "Factors Determining Adoption of New Agricultural Technology by Smallholder Farmers in Developing Countries". Issn, 6.5 (2015): 2222-1700.

9. Rogers E. "Diffusion of Innovation 4th edition". Free Press (1995).

10. Anderson JR and Feder G. "Agricultural Extension: Good extension and hard realities". World Bank Researcher Observer Journal 19.1 (2004): 41-60.
11. Poudel M., et al. "Economics of Rubber Production in Jhapa, Nepal". Journal of Agriculture and Natural Resources 3.1 (2020): 198-208.

12. Doss C R. Understanding Farm-level Technology Adoption : Lessons Learned from CIMMYT' s Micro Surveys in Eastern Africa. CIMMYT Economics Working Paper 03-07 (2003): 26.

13. Suvedi M., et al. "Farmers' participation in extension programs and technology adoption in rural Nepal: a logistic regression analysis". Journal of Agricultural Education and Extension 23.4 (2017): 351-371.

14. Xiloyannis C., et al. "Orchard management". Acta Horticulturae 488 (2017): 457-464.

15. Chaudhary Ravish., et al. "Adoption of improved production technology of Mandarin in Rajasthan, India: A review". African Journal of Agricultural Research 8.49 (2013): 6590-6633.

16. Prodhan M M H and Khan M A. "Management practice adoption and productivity of commercial aquaculture farms in selected areas of Bangladesh". Journal of the Bangladesh Agricultural University 16.1 (2018): 111-116.

17. Bilaliib Udimal T., et al. "Factors Influencing the Agricultural Technology Adoption: The Case of Improved Rice Varieties (Nerica) in the Northern Region, Ghana". Journal of Economics and Sustainable Development 8.8 (2017): 2222-1700.

18. Ntshangase N L., et al. "Farmers' perceptions and factors influencing the adoption of no-till conservation agriculture by small-scale farmers in Zashuke, KwaZulu-Natal province. Sustainability (Switzerland) 10.2 (2018).

19. Sriyalatha M A K. "Factors Affecting Natural Rubber Production: Case Study of Small Rubber Farmers In Kalutara District, Sri Lanka". IOSR Journal of Business and Management (IOSRJBM) 20.9 (2018): 64-73.

\section{Assets from publication with us}

- Prompt Acknowledgement after receiving the article

- Thorough Double blinded peer review

- Rapid Publication

- Issue of Publication Certificate

- High visibility of your Published work

Website: www.actascientific.com/

Submit Article: www.actascientific.com/submission.php

Email us: editor@actascientific.com

Contact us: +919182824667 